\title{
Development of Solid SEDDS, IV: Effect of Adsorbed Lipid and Surfactant on Tableting Properties and Surface Structures of Different Silicates
}

\author{
Suhas G. Gumaste • Sara A. Pawlak • Damon M. Dalrymple • Charles J. Nider • Louis D. Trombetta • Abu T. M. Serajuddin
}

Received: 7 January 2013 / Accepted: 4 June 2013 / Published online: 26 June 2013

(C) The Author(s) 2013. This article is published with open access at Springerlink.com

\begin{abstract}
Purpose To compare six commonly available silicates for their suitability to develop tablets by adsorbing components of liquid lipid-based drug delivery systems.

Methods The tabletability of Aerosil ${ }^{\circledR} 200$, Sipernat $\AA 22$, Sylysia ${ }^{\circledR}$ 350, Zeopharm ${ }^{\circledR} 600$, Neusilin ${ }^{\circledR}$ US2 and Neusilin ${ }^{\circledR}$ UFL2 were studied by compressing each silicate into tablets in the presence of $20 \%$ microcrystalline cellulose and measuring the tensile strength of tablets produced. Three components of lipid based formulations, namely, Capmul ${ }^{\circledR}$ MCM EP (glycerol monocaprylocaprate), Captex ${ }^{\circledR} 355$ EP/NF (caprylic/capric triglycerides) and Cremophor ${ }^{\circledR}$ EL (PEG-35 castor oil), were adsorbed individually onto the silicates at $I: I W / W$, and the mixtures were then compressed into tablets. The SEM photomicrographs of neat silicates and their $1: 1$ W/W mixtures (also 1:2 and 1:3 for Neusilin ${ }^{\circledR}$ US2 and Neusilin ${ }^{\circledR}$ UFL2) with one of the liquids (Cremophor ${ }^{\circledR} \mathrm{EL}$ ) were recorded.

Results Neat Aerosil ${ }^{\circledR} 200$, Sipernat ${ }^{\circledR} 22$ and Sylysia $₫ 350$ were non-tabletable to the minimum acceptable tensile strength of I MPa, and they were also non-tabletable in presence of liquid. While Zeopharm ${ }^{\circledR}$ 600, Neusilin ${ }^{\circledR}$ US2 and Neusilin ${ }^{\circledR}$ UFL2 were tabletable without the addition of liquids, only Neusilin ${ }^{\circledR}$ US2 retained acceptable tabletability with I:I liquid. The SEM images of silicateliquid mixtures indicated that, except for Neusilin ${ }^{\circledR}$ US2, much of the adsorbed liquid distributed primarily at the surface of particles rather than inside pores, which hindered their compaction into tablets.
\end{abstract}

Conclusion Among the six silicates studied, Neusilin ${ }^{\circledR}$ US2 was the only silicate able to produce tablets with acceptable tensile strength in presence of a lipid component at $1: 1 \mathrm{w} / \mathrm{W}$ ratio due to the fact that the liquid was mostly adsorbed into the pores of the silicate rather than at the surface.

S. G. Gumaste · S. A. Pawlak • L. D. Trombetta •

A. T. M. Serajuddin $(\bowtie)$

Department of Pharmaceutical Sciences, College of Pharmacy

and Health Sciences, St. John's University

8000 Utopia Parkway, Queens, New York I I439, USA

e-mail: serajuda@stjohns.edu

D. M. Dalrymple • C. J. Nider

ABITEC Corporation 50I W. Ist Avenue, Columbus, Ohio 432I5, USA
KEY WORDS adsorption · comparative evaluation · lipid

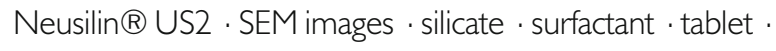
tabletability

\section{INTRODUCTION}

There has been a great interest in the pharmaceutical field in the use of silicates for the development of oral dosage forms, especially to enhance dissolution rate and bioavailability of poorly water soluble drugs by adsorbing them onto silicates in amorphous forms or as solutions (1-8). Having high surface area and commonly being porous, silicates are capable of adsorbing liquids, often as much as 2 to 3 times their own weights. They were first utilized by Jarowski et al. (9) for adsorbing organic solutions of poorly water-soluble drugs, and, in more recent years, they were investigated for adsorbing self-emulsifying drug delivery systems to convert them into dry powders (10-14). However, such a formulation approach often led to the development of powder-filled hard gelatin capsule formulations as the silicates were inherently non-compactible or the loading of liquids prevented their compression into tablets (15). The amount of materials that could be delivered in a unit dose of capsule was limited to a relatively low maximum amount of about 300-400 mg of powder for a capsule suitable for oral administration. On the other hand, as much as $1 \mathrm{~g}$ or even a higher amount of powder may be compressed into a unit tablet. Considering a tablet weight of $1 \mathrm{~g}$ and the liquid to silica ratio of $1: 1$, this would lead to a tablet with $500 \mathrm{mg}$ of liquid component, which is not possible in a powder-filled capsule.

Despite obvious advantages of tablet formulations, there are only limited studies on the development of tablet dosage forms for lipid-based drug delivery systems reported in the literature. The poor tabletability of powders loaded with liquid lipids and surfactants into tablets has been the major development issue. Sander and Holm (3) reported that when the liquid-loaded powders are compressed, there is a lack of tablet hardness due to the squeezing out of oily liquid from 
the solid, especially at the relatively high liquid load. It is, therefore, of interest to determine the tableting properties of various silicates in presence of lipids and surfactants. In two recent studies published in 2012, the tableting properties of several silicates were investigated $(16,17)$. Hentzschel et al. (16) measured the tensile strength of four silicates, namely, Aerosil, Aerogel, Neusilin and Florite, as a function of compression pressure to determine their suitability as tableting excipients. It was observed that three of them, Aerogel, Neusilin and Florite, had acceptable tablet hardness. However, only the neat silicates or the mixtures of silicates with microcrystalline cellulose (Avicel) were used in these studies and no lipids or surfactants were added. Mura et al. (17) adsorbed a selfmicroemulsifying formulation onto several silicates before determining their tabletability. They observed that only one of the silicate used, Neusilin ${ }^{\circledR}$ US2, had acceptable tableting properties. The lipid-based formulation used in this study consisted primarily of the mixture of a surfactant (47\%) and an organic solvent $(47 \%)$, and the concentration of lipid component was relatively low $(6 \%)$.

The present study has been undertaken to compare six commonly available silicates from different manufactures for their tabletability after loading two medium chain lipids and a surfactant individually. The two representative lipids, Capmul ${ }^{\circledR}$ MCM EP (glycerol monocaprylocaprate) and Captex® $355 \mathrm{EP} / \mathrm{NF}$ (caprylic/capric triglycerides), and the surfactant, Cremophor ${ }^{\circledR}$ EL (PEG-35 castor oil), selected for the present study are commonly used in the development of SEDDS (18). To date, silicates are usually used in the development of solid dosage forms as glidants to enhance flowability of powders by reducing interparticular cohesion and adhesion (19). Therefore, all the silicates used in the present investigation were not necessarily manufactured and marketed for the application of adsorbing liquids. However, the focus of the present investigation has been the tabletability of silicates after adsorption of lipids and surfactants and no other application of the silicates was investigated. In addition to studying tabletability, the surface structure and relative particle sizes of the silicates, the nature of their pores and how the liquids were absorbed and distributed within the pores or at the surface were examined. This was done by the scanning electron microscopic (SEM) analysis of each silicate, with and without the loading of liquid. Such a SEM analysis may be able to explain the effect of adsorbed lipids and surfactants on the tabletability of different solid formulations.

\section{MATERIALS AND METHODS}

\section{Materials}

Two medium chain lipids, Capmul ${ }^{\circledR}$ MCM EP (glycerol monocaprylocaprate) and Captex ${ }^{\circledR} 355 \mathrm{EP} / \mathrm{NF}$ (caprylic/capric triglycerides) were used. They were obtained from ABITEC Corp., Columbus, OH, USA. The surfactant, Cremophor ${ }^{\circledR}$ EL (PEG-35 castor oil) was obtained from BASF, Tarrytown, NY, USA. Compositions of lipids and the surfactant used and structures of their primary components were reported earlier (18). Various silicates used, along with names of their manufacturers, are listed in Table I. The microcrystalline cellulose NF (Vivapur® 112) was obtained from JRS Pharma, Rosenberg, Germany.

\section{Tableting of Silicates without Added Lipids}

Most of the available silicates are inherently non-tabletable (20) and, as shown in Table I, have very low bulk density. The bulk density of Aerosil 200®, for example, was extremely low. Therefore, the tabletability of different silicates used in this study was compared by mixing them with $20 \% \mathrm{w} / \mathrm{w}$ microcrystalline cellulose NF (MCG). Since the same concentration of microcrystalline cellulose was present with all silicates, the determination of relative tabletability of different silicates was possible.

Formulations weighing $c a .400 \mathrm{mg}$ that contained $20 \% \mathrm{w} / \mathrm{w}$ microcrystalline cellulose and $80 \% \mathrm{w} / \mathrm{w}$ silica were compressed at 50, 150 and $250 \mathrm{MPa}$ using $14 \mathrm{~mm}$ flat face punches (Natoli Engineering, Saint Charles, MO, USA) on a single punch Carver Press assembly (Carver Inc., Wabash, IN, USA). Tablet hardness was determined using a PAH-01 hardness tester (Pharma Alliance, Valencia, CA, USA). Tablet dimensions were then used to calculate the tensile strengths $(\rho)$ of the tablets using the following equation:

$\rho=2 F / \pi \mathrm{DT}$

where $\mathrm{F}$ is the breaking force, $\mathrm{D}$ and $\mathrm{T}$ are the diameter and thickness, respectively (21). Since the hardness of tablets as determined by the hardness tester varies depending on the tablet size, the calculation of tensile strength in this way normalized the size difference.

\section{Liquid Loading onto Silicates}

Initially, attempts were made to incorporate the lipids and the surfactant with silicates by mixing the liquids and the silicates at 1:1 ratios in beakers with the help of a spatula or by levigating them with a mortar and a pestle. However, the process was unable to distribute lipids uniformly in some of the silicates and the powders produced in several cases resulted into lumps with poor flow properties. In several studies reported in the literature, the lipid-based formulations were adsorbed onto solid carriers by first dissolving them in volatile organic solvents and then adding dry carrier powders to these solutions, which was followed by drying of the mixtures (22,23). A similar method was adopted in the present study for screening 


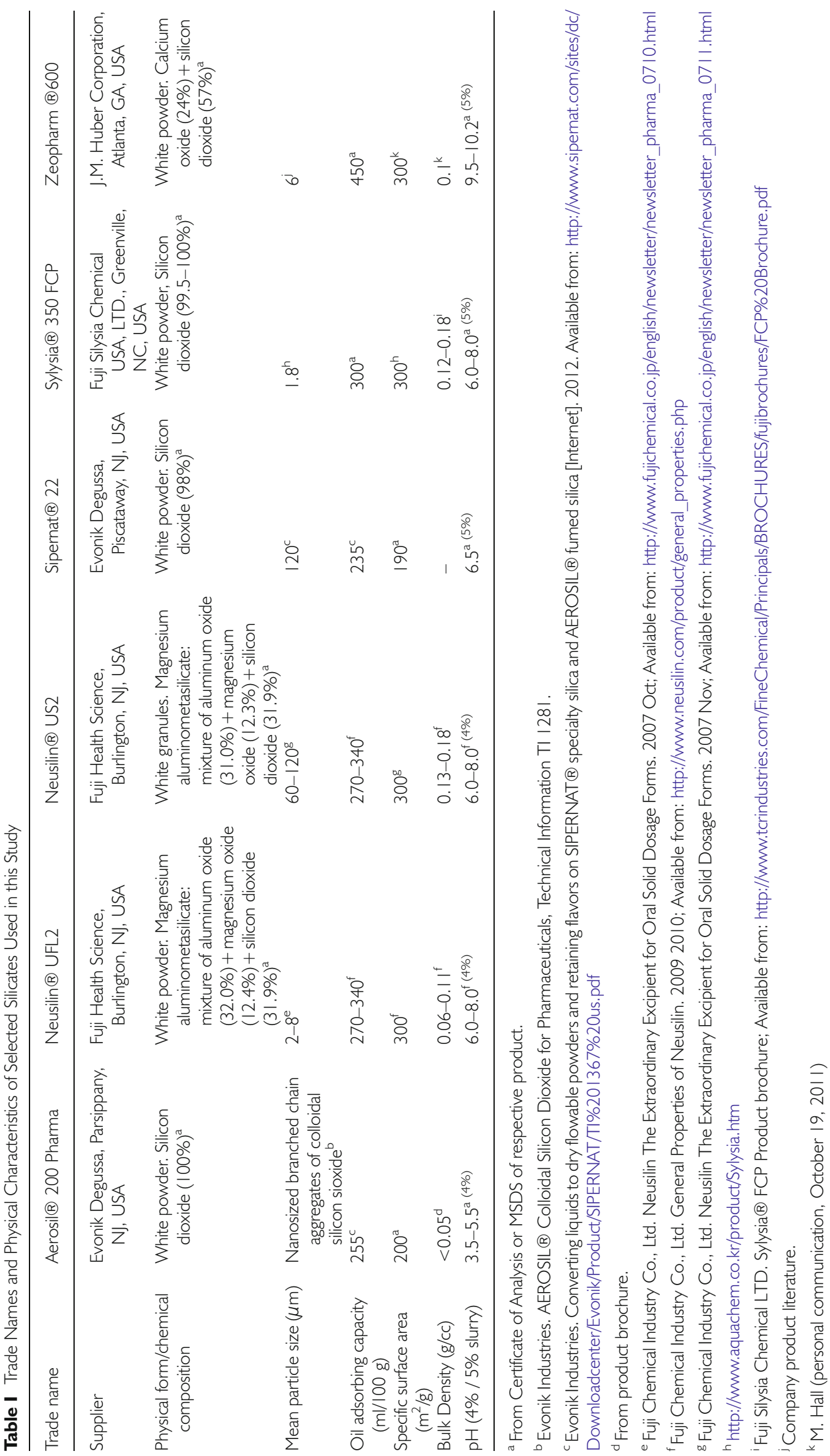


various silicates for their suitability as carriers for lipids and surfactants. Capmul ${ }^{\circledR}$ MCM EP, Captex ${ }^{\circledR} 355$ and Chremophor ${ }^{\circledR}$ EL were dissolved separately in minimum necessary amounts of isopropanol. Silicates were then added to the alcoholic solution to produce slurries such that the silicate to lipid (or surfactant) ratio was 1:1 w/w. The slurries were dried by placing them on open petri dishes at room temperature in a fume hood for 2 days. The materials were mixed intermittently with a spatula to facilitate drying. Freeflowing and lump-free powders were obtained. It was confirmed by weighing the powders after drying that there was a complete evaporation of isopropanol. The powders were then passed through a sieve of $800-\mu \mathrm{m}$ pore size before further use.

\section{Tableting of Liquid-Loaded Powders}

Formulations containing approximately 50\% w/w silicate and $50 \% \mathrm{w} / \mathrm{w}$ lipid or surfactant and weighing $c a$. $800 \mathrm{mg}$ were compressed at pressures ranging from $45 \mathrm{MPa}$ to $270 \mathrm{MPa}$ using $14 \mathrm{~mm}$ flat face punches (Natoli Engineering) on a single punch Carver Press assembly (Carver Inc.). No microcrystalline cellulose was added with the liquid-loaded silicates as it was found that some of the neat silicates could be compressed into hard tablets even without adding microcrystalline cellulose and the primary purpose of these experiments was to determine what effects the adsorbed liquids would have on the tabletability of silicates. Tablet tensile strength was calculated as described earlier.

\section{Scanning Electron Microscopy (SEM)}

\section{Preparation of Samples}

The SEM study was conducted for the neat silicates as well as for the silicate-liquid mixtures. Since the two lipids and the surfactant used behaved similarly in the tableting study, only one of them, Cremophor ${ }^{\circledR}$ EL, was used for the SEM study of mixtures. Samples with the 1:1 w/w ratio of silicate and Cremophor $®$ EL was prepared for all silicates by the method described earlier in this paper. Additionally, 1:2 and 1:3 w/w ratios of silicate to Cremophor ${ }^{\circledR}$ EL was prepared for two of the silicates (Neusilin ${ }^{\circledR}$ US2 and Neusilin ${ }^{\circledR}$ UFL2) that showed promising tableting properties with the addition of lipid or surfactant.

\section{Recording of SEM Images}

The samples were stored in closed vials prior to analysis. SEM stubs were sterilized in acetone for $1 \mathrm{~min}$, and then a light dusting of each sample was adhered to the stub using carbon tape. Next, the samples were platinum coated using an EMS 550X sputter coater (Electron Microscopy Sciences, Hatfield, PA, USA) at $25 \mathrm{~mA}$. Most samples were coated for $\sim 4$ min; only a few samples were coated for $\sim 2$ min. The samples were then observed under a variety of accelerating voltages using a JEOL JSM-6010 analytical scanning electron microscope (JEOL Ltd, Tokyo, Japan). The micrographs were digitally captured at 5 and $10 \mathrm{kV}$.

\section{RESULTS AND DISCUSSION}

\section{Tabletability of Silicates without Liquid Adsorption}

Tabletability may be defined as the capacity of a powder to be transformed into a tablet of specified strength under the effect of a certain compaction pressure (24). It is typically characterized by plotting tablet tensile strength as a function of compaction pressure.

Table II shows the tabletability profiles of the selected silicates in presence of 20\% MCC. To obtain a preliminary insight into the tabletability behavior of these formulations, three compaction pressures (viz. $50 \mathrm{MPa}, 150 \mathrm{MPa}$ and $200 \mathrm{MPa}$ ) representing a relatively wide range of compaction behavior were utilized. Tensile strength values in excess of $1 \mathrm{MPa}$ are typically desired for tablets to withstand stress during their lifetime (25). Among the silicates tested, only Neusilin ${ }^{\circledR}$ US2 and Neusilin ${ }^{\circledR}$ UFL2 could produce tablets with a tensile strength of $\geq 1 \mathrm{MPa}$ under all three compression pressures used, while Zeopharm ${ }^{\circledR} \quad 600$ exhibited high tensile strengths at compression pressures of 150 and $250 \mathrm{MPa}$, which were comparable to that of Neusilin ${ }^{\circledR}$ US2 and Neusilin ${ }^{\circledR}$ UFL2. Sipernat ${ }^{\circledR} 22$ could produce a tensile strength of $1.2 \mathrm{MPa}$ at a compaction pressure of $250 \mathrm{MPa}$; however, the value was about one-fourth of that produced by Zeopharm ${ }^{\circledR} 600$, Neusilin ${ }^{\circledR}$ UFL2 and Neusilin ${ }^{\circledR}$ US2. Aerosil ${ }^{\circledR} 200$ and Sylysia $350 \AA$ produced tablets of poor tensile strength,

Table II Tabletability (Tensile Strength in $\mathrm{MPa}$ ) of Selected Silicates Blended with 20\% w/w MCC (Average of 2 Determinations)

\begin{tabular}{llll}
\hline $\begin{array}{l}\text { Silicate used (+20\% w/W } \\
\text { microcrystalline cellulose) }\end{array}$ & \multicolumn{3}{l}{$\begin{array}{l}\text { Tensile strength }(\mathrm{MPa}) \text { at different } \\
\text { compression pressure }\end{array}$} \\
\cline { 2 - 4 } & $50 \mathrm{MPa}^{\mathrm{a}}$ & $150 \mathrm{MPa}^{\mathrm{a}}$ & $250 \mathrm{MPa}^{\mathrm{a}}$ \\
\hline Aerosil ${ }^{\circledR} 200$ & 0.1 & 0.4 & Broken \\
Neusilin ${ }^{\circledR}$ UFL2 & 1.4 & 4.4 & 5.0 \\
Neusilin ${ }^{\circledR}$ US2 & 1.2 & 5.3 & 4.6 \\
Sipernat@ 22 & Broken & 0.6 & 1.2 \\
Sylysia ${ }^{\circledR} 350$ & 0.1 & 0.9 & Laminated \\
Zeopharm ${ }^{\circledR} 600$ & 0.6 & 5.5 & 5.0 \\
\hline
\end{tabular}

${ }^{\mathrm{a}}$ Compression pressure 
which broke or laminated at high pressure. Formulations of Aerosil ${ }^{\circledR} 200$ and Sylysia $350 \AA$ were also very difficult to handle due to low bulk density of materials and the tendency to form aggregates. Since very high tablet tensile strengths $(>5 \mathrm{MPa}$ ) could be obtained with some of the formulations at merely $20 \%$ MCG load, addition of MCG at higher concentrations was not considered to be important in comparing tableting properties of different silicates.

\section{Tabletability of Silicates in Presence of Lipids and Surfactant}

Since Neusilin ${ }^{\circledR}$ US2, Neusilin ${ }^{\circledR}$ UFL2 and Zeopharm ${ }^{\circledR}$ 600 exhibited acceptable tableting properties when used without the adsorption of liquids, it was of interest to determine how will they behave when lipids and surfactants are adsorbed onto them. The tabletability of other three silicates (Aerosil 200, Sipernet 22 and Sylysia 350) was also studied to determine what effects the adsorbed lipids and surfactant would have on their tabletability.

The results of the tabletability of various silicates in presence of Capmul® MCM, Captex ${ }^{\circledR} 355$ and Cremophor ${ }^{\circledR}$ EL are, respectively, shown in Fig. 1a, b and c. No microcrystalline cellulose was added in preparing these tablets. It is evident from the figures that only Neusilin ${ }^{\circledR}$ US2 and Neusilin ${ }^{\circledR}$ UFL2 could produce tablets with tensile strength equivalent to or higher than $1 \mathrm{MPa}$. The tablets obtained with the other silicates were soft and oily, which often laminated or capped and in some cases even stuck to the punches. However, irrespective of such anomalies, all tablets were analyzed for their tensile strengths and the values reported. Between Neusilin ${ }^{\circledR}$ US2 and Neusilin ${ }^{\circledR}$ UFL2, the later could produce acceptable tablets $(\sim 1 \mathrm{MPa})$ at the low pressures $45 \mathrm{MPa}$ and its tabletability decreased at higher pressures. Although Zeopharm ${ }^{\circledR} 600$ produced excellent tablets in the absence of liquid load where its tensile strengths were similar to those of Neusilin ${ }^{\circledR}$ US2, it failed to produce acceptable tablets in presence of adsorbed lipids and surfactant. Indeed, the tabletability of Zeopharm ${ }^{\circledR} 600$ in presence of the liquid was very similar to that of the other silicates that did not produce acceptable tablets without adsorbed liquids. It is, therefore, evident from Fig. la, b and c that Neusilin ${ }^{\circledR}$ US2 outperformed all other silicates tested in the present investigation with respect to their tabletability. Neusilin ${ }^{\circledR}$ US2 did this by exhibiting superior tensile strength at the $1: 1 \mathrm{w} / \mathrm{w}$ loading of lipids and surfactant. The appearance Neusilin ${ }^{\circledR}$ US2 tablets were also excellent, irrespective of the type of liquid and the amount of compression pressure used, which ranged from 45 to $270 \mathrm{MPa}$. The tabletability of Neusilin ${ }^{\circledR}$ US2, however, decreased below the acceptable limit when the liquid load was increased to 1:2 and 1:3 w/w (data not shown). Using blends of a liquid, tocopherol acetate, and several
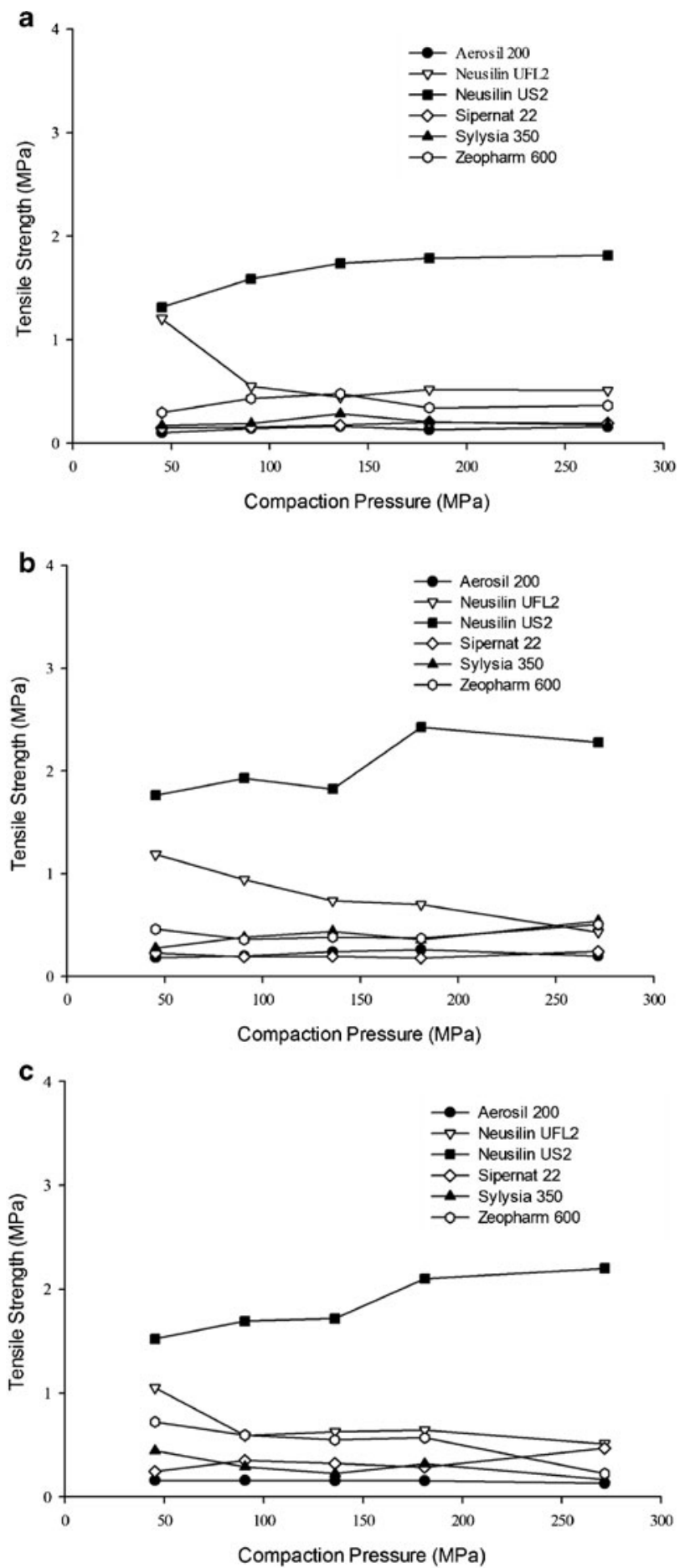

Fig. I Tabletability of selected carriers at I:I w/w ratio with (a) glycerol monocaprylocaprate (Capmul ${ }^{\circledR}$ MCM EP), (b) caprylic/capric triglyceride (Captex $\left.{ }^{\circledR} 355\right)$, and (c) PEG-35 castor oil (Cremophor ${ }^{\circledR}$ EL). Each data point is the average of 2 separated determinations.

silicates, Hentzschel et al. (23) observed that, unlike most other silicates, Neusilin ${ }^{\circledR}$ US2 exhibits good tabletability. Thus, the results of the present investigation are also in agreement with previous observations by other investigators. 
As shown in Tables I and II and also reported in the literature (20), most silicates used in pharmaceutical products exhibit very low bulk densities and lack inherent tabletability. It was observed in the present study that there was a significant improvement in the densities of the silicates after loading of liquids (data not shown). However, such an increase in density did not have any positive impact on the tabletability of silicates. Khan et al. $(15,26)$ used additional excipients, such as microcrystalline cellulose, to increase the tabletability of silicates with adsorbed lipids and surfactants. Although helpful, such addition of other excipients increases the tablet weight and may, indeed, reduce the lipid and surfactant load and hence the drug load in the tablet drastically, especially when the drug solubility in the lipid is low or the dose is high. For this reason, the $1: 1 \mathrm{w} / \mathrm{w}$ ratio of the adsorbed liquid to the silicate, without the addition of any tableting aid like microcrystalline cellulose, was selected in the present study as the initial acceptance criteria for the lipid-based tablet formulations.

Figure 2 shows the effect of lipid and surfactant on the tabletability of Neusilin ${ }^{\circledR}$ US2. Since Neusilin ${ }^{\circledR}$ US2 by itself could also be compressed into tablets, the neat silicate rather than its mixture with $20 \% \mathrm{w} / \mathrm{w}$ microcrystalline cellulose was used for comparison with the ones containing two lipids and one surfactant. As mentioned earlier, the tabletability of Neusilin ${ }^{\circledR}$ US2 in presence of $1: 1 \mathrm{w} / \mathrm{w}$ liquid load was found to be acceptable (Fig. 1a, b and c). However, the comparative data in Fig. 2 demonstrate that the tabletability of Neusilin ${ }^{\circledR}$ US2 decreased drastically upon the loading of liquids (ca. $6 \mathrm{MPa}$ for neat silicate at the compaction pressure of $135 \mathrm{MPa}$ versus ca. $2 \mathrm{MPa}$ in presence of liquid at the same pressure). The distinct loss of

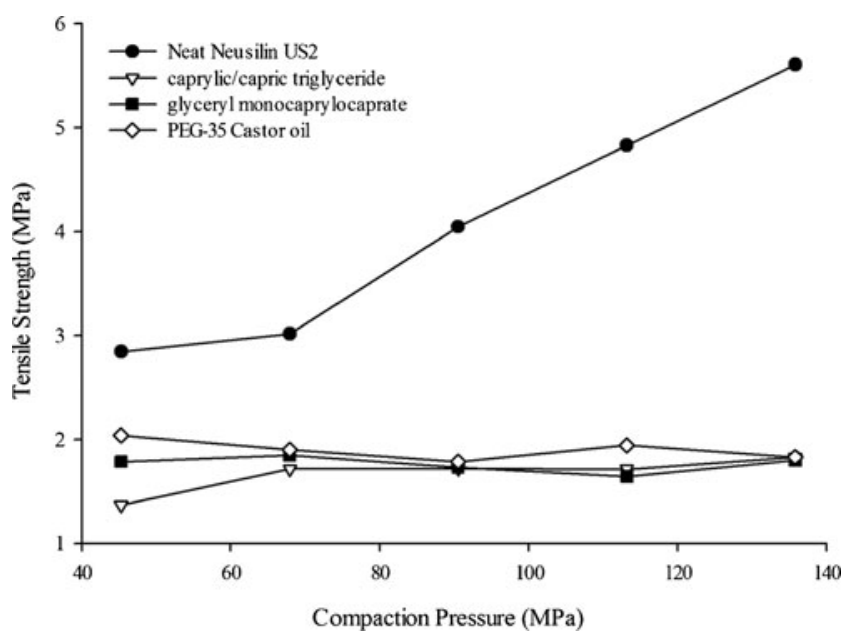

Fig. 2 Comparative tabletability of Neusilin ${ }^{\circledR}$ US2 without and with the liquid load. Data for neat Neusilin ${ }^{\circledR}$ US2 vs. Neusilin ${ }^{\circledR}$ US2 loaded with glycerol monocaprylocaprate (Capmul ${ }^{\circledR}$ MCM EP), caprylic/capric triglyceride (Captex $\left.{ }^{\circledR} 355\right)$ and PEG-35 castor oil at I:I w/W ratio are shown $(n=1)$. tabletability in presence of lipid and surfactant could be attributed to the interparticulate spreading of the liquid in the tablet bed, thus interfering in the bonding between silicate particles.

\section{Effect of Type of Liquid Component on Tabletability}

The physics of adsorption of liquid solutions of drugs onto mesoporous substances like Neusilin ${ }^{\circledR}$ US2 was described and reviewed by Qian and Bogner (7). Although the adsorption of liquids on silicates is expected to be a completely physical process, it was of interest to see if there was any effect of individual liquid components (Capmul ${ }^{\circledR}$ MCM EP, Captex ${ }^{\circledR} 355$ and Cremophor ${ }^{\circledR}$ EL) of lipid-based drug delivery systems on the tabletability of the silicates. It may be observed from Fig. 1a, b and c that there was no difference among the three liquids (two lipids and one surfactant) used in the present study on their impact on tabletability of silicates. If at all, the difference was marginal and not significant.

\section{Effect of Particle Size}

The exact physicochemical basis of the good tabletability exhibited by Neusilin ${ }^{\circledR}$ US2 is not known. It could possibly be attributed to its chemical composition, relatively large particle size and porous granular nature. To ascertain the effect of particle size on the tabletability of Neusilin ${ }^{\circledR}$ US2,

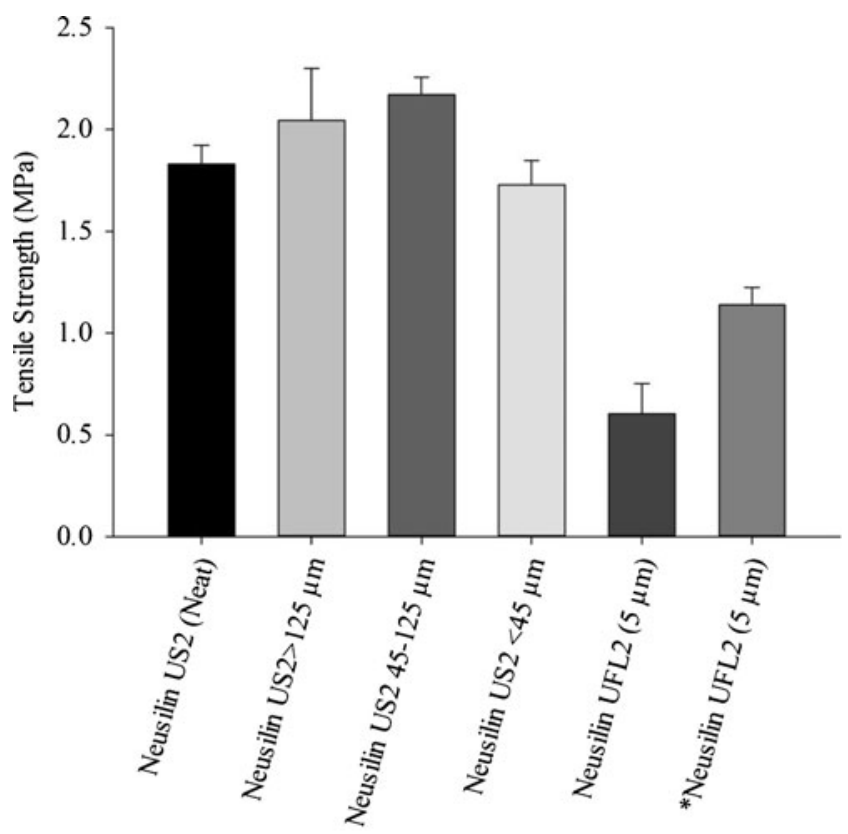

Silica Particle Size and Type

Fig. 3 Effect of particle size on the tabletability of Neusilin ${ }^{\circledR}$ US 2 and Neusilin ${ }^{\circledR}$ UFL2 loaded with Cremophor ${ }^{\circledR}$ EL at I:I w/w ratio and compressed at $135 \mathrm{MPa}$. *UFL2 $(5 \mu \mathrm{m})$ compressed at $45 \mathrm{MPa}$. $(n=3 \pm$ s.d.) 

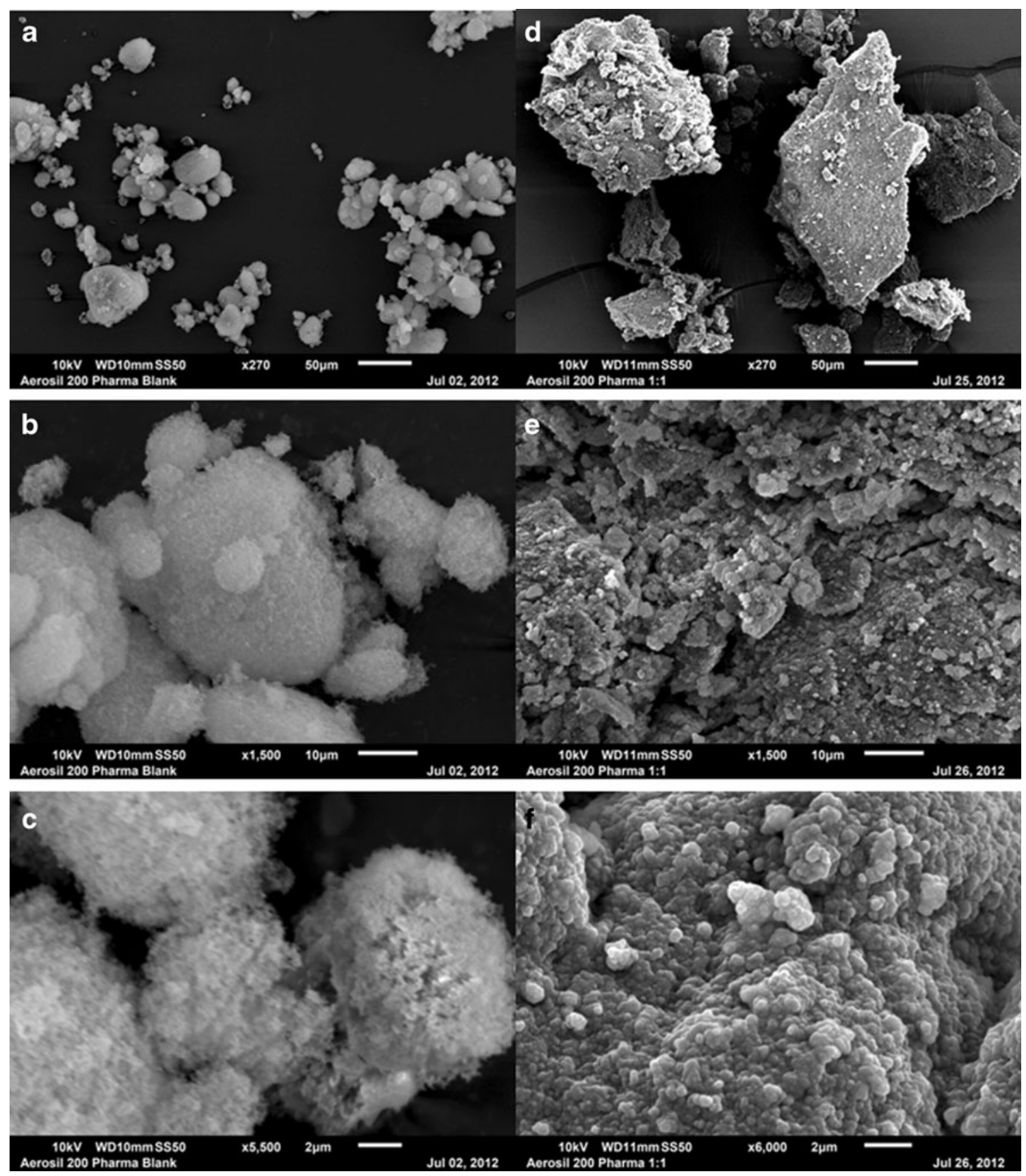

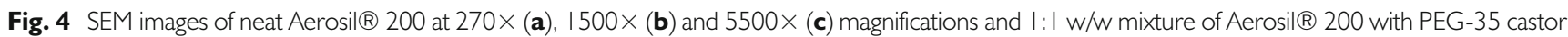
oil (Cremophor ${ }^{\circledR}$ EL) at $270 \times(\mathbf{d}), 1500 \times(\mathbf{e})$ and $6000 \times(\mathbf{f})$ magnifications. A microscope scale is shown in each image for comparison of dimensions.

an experiment was conducted where Neusilin ${ }^{\circledR}$ US2 was sieved through No. $120(125 \mu \mathrm{m})$ and No. $325(45 \mu \mathrm{m})$ sieves. One of the liquids, Cremophor ${ }^{\circledR}$ EL, was then adsorbed at the $1: 1 \mathrm{w} / \mathrm{w}$ ratio onto the three sieve fractions with high, intermediate and low particle sizes of Neusilin ${ }^{\circledR}$ US2 $(>125,45-125$ and $<45 \mu \mathrm{m})$. As shown in Fig. 3, there was no major difference in tensile strengths of the three sieved fractions of Neusilin ${ }^{\circledR}$ US2 as the values ranged from $\sim 1.6$ to $2.1 \mathrm{MPa}$. The values were also essentially similar to that of the non-sieved material.
Since the difference in the tensile strength of different Neusilin ${ }^{\circledR}$ US2 particle fractions ranging from $<45 \mu \mathrm{m}$ to $>125 \mu \mathrm{m}$ was only marginal, further investigation of the effect of particle size on tabletability was conducted using Neusilin ${ }^{\circledR}$ UFL2, which is compositionally similar to Neusilin ${ }^{\circledR}$ US2 (Table I) but had a much lower particle size $(<5 \mu \mathrm{m})$. The results are also given in Fig. 3, showing that at the 1:1 w/w ratio with the liquids Neusilin ${ }^{\circledR}$ UFL2 exhibited poor tabletability having the tensile strength of $<1 \mathrm{MPa}$. These results presented in Fig. 3 are in agreement with those observed in Fig. 1. Thus, it is apparent 

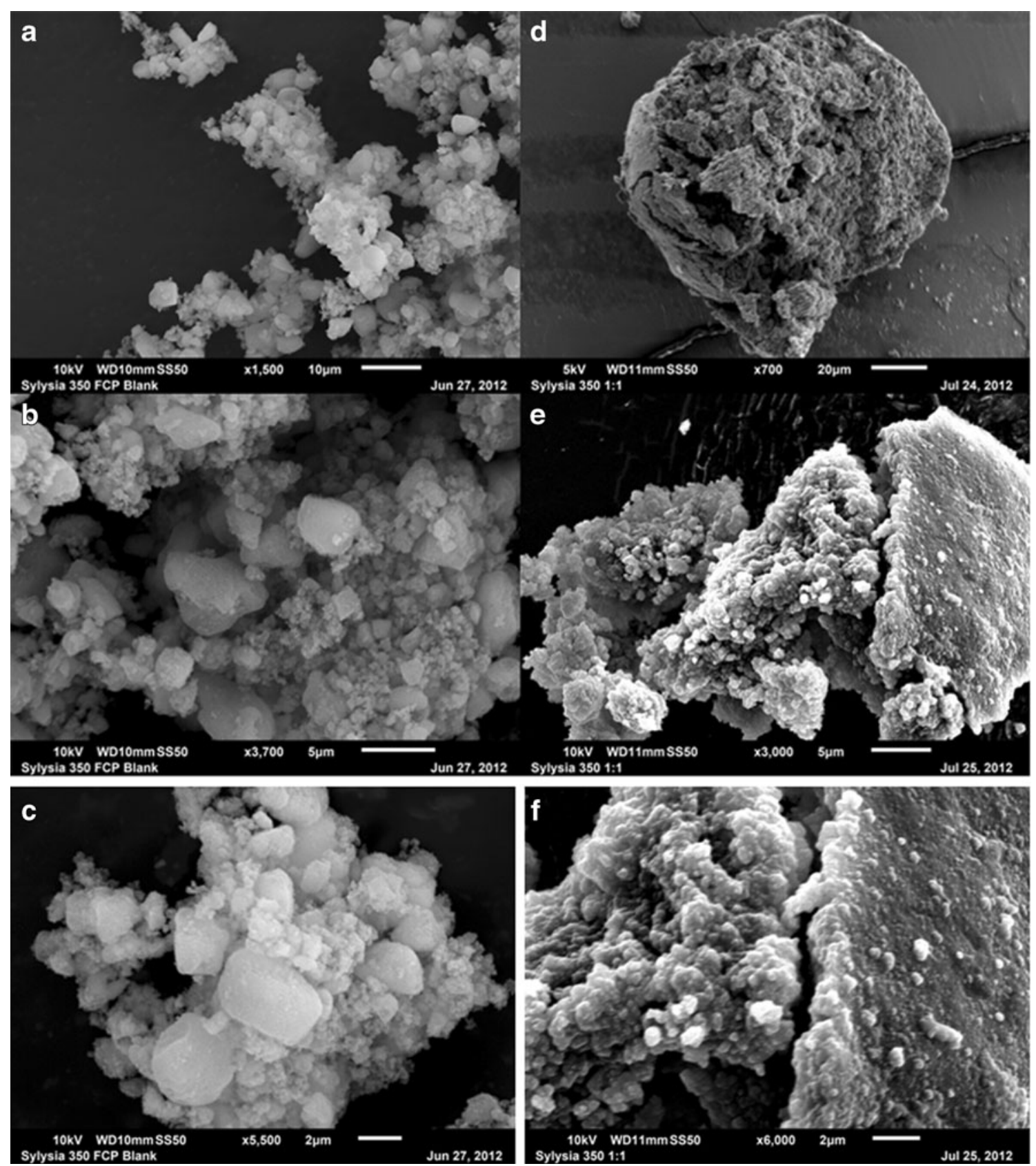

Fig. 5 SEM images of neat Sylysia ${ }^{\circledR} 350$ FCP at I $500 \times(\mathbf{a}), 3700 \times(\mathbf{b})$ and $5500 \times(\mathbf{c})$ magnifications and I : I w/w mixture of Sylysia $₫ 350$ FCP with PEG35 Castor oil (Cremophor ${ }^{\circledR}$ EL) at $700 \times(\mathbf{d}), 3000 \times(\mathbf{e})$ and $6000 \times(\mathbf{f})$ magnifications. A microscope scale is shown in each image for comparison of dimensions.

that a relatively large difference in particle size of the same class of silicates (for example, Neusilin ${ }^{\circledR}$ US2 vs. Neusilin ${ }^{\circledR}$ UFL2) can influence the tabletability of material after adsorption of lipids and surfactants. The relatively larger particle size of the same class of silicates appears to favor the development of tablet formulations for lipid-based drug delivery systems.

It is possible that when a liquid is loaded onto larger Neusilin ${ }^{\circledR}$ US2 particles most of it is adsorbed deeper inside the pores and, therefore, a relatively lesser amount covers the particle surface. On the other hand, for smaller particles the adsorbed liquid tends to stay closer to the surface of the particles and they may be squeezed out more easily by the pressure applied during tableting. As a result, the inter-particulate bonding between the carrier particles of the later systems could be heavily interfered by the presence of liquids. The decrease in tabletability of Neusilin ${ }^{\circledR}$ UFL2 with smaller particle size may, thus, be attributed to the liquids staving onto or closer to the surface of such particles. It may also explain the decrease in tensile strength with the increase in compression pressure observed for Neusilin ${ }^{\circledR}$ UFL2 in Fig. 1a, b and c. It is possible that 
more of the liquid squeezed out of the pores at higher compression pressure, which decreased the tensile strength of tablets.

Unlike Neusilin ${ }^{\circledR}$ US2, tablets made up of Sipernat ${ }^{\circledR} 22$ having an average particle size of $110 \mu \mathrm{m}$, which is essentially similar to that of Neusilin ${ }^{\circledR}$ US2, exhibited poor tabletability (tensile strengths $<1 \mathrm{MPa}$; Fig. 1a, b and c) when loaded at 1:1 ratio with Cremophor ${ }^{\circledR}$ EL. It is, therefore, evident that certain properties of silicates other than particle size may also influence the tablet development of lipid-based systems.

\section{SEM Study}

Although many different studies on the adsorption of lipids and surfactants onto silicates were reported in the literature, there is no systematic investigation on why certain silicates exhibit acceptable tabletability while others do not. In the present investigation, the surface structures of six different silicates were studied, with and without the adsorption of a liquid component, for an insight into their tabletability. Although two lipids and one surfactant have been used in compression studies, Fig. 1 shows that all of them have similar effects on the tabletability of silicates. All three of them also showed similar SEM micrographs when adsorbed onto silicates. Therefore, the detailed SEM studies were conducted using only PEG-35 castor oil (Cremophor ${ }^{\circledR}$ EL).

\section{Aerosil $\AA 200$}

Figure 4 shows the SEM micrographs of Aerosil ${ }^{\circledR} 200$ as neat material and after adsoption of Cremophor ${ }^{\circledR}$ EL at 1:1 $\mathrm{w} / \mathrm{w}$ ratio. The depths of the microscopic fields give a three dimensional perceptions of the SEM images. In the left hand column of Fig. 4, the top image (Fig. 4a) shows the neat material $270 \times$ magnification, which is then followed by the images of the same material at $1500 \times$ and $5500 \times$ magnifications (Fig. 4b and c, respectively). Scales of 50, 10 and $2 \mu \mathrm{m}$ are shown in Fig. 4a, b and c, respectively, for an overview of the particle size of the material. It is apparent that Aerosil ${ }^{\circledR} 200$ exists as loose aggregates of very fine particles. Even at the magnification of $5500 \times$ and the scale of $2 \mu \mathrm{m}$ (Fig. 4c), the material exhibits aggregation. These results are in agreement with the description of Aerosil ${ }^{\circledR} 200$ in Table I to be nanosized aggregates of silicon dioxide.

Unlike the neat material, Aerosil ${ }^{\circledR} 200$ formed relatively large granules when Cremophor ${ }^{\circledR}$ EL was adsorbed onto it at $1: 1 \mathrm{w} / \mathrm{w}$ ratio $($ Fig. $4 \mathrm{~d}$, e and $\mathrm{f}$ at, respectively, 270×, $1500 \times$ and $6000 \times$ magnifications). In contrast to the extremely fine nanosized particles of neat Aerosil ${ }^{\circledR} 200$, the granules are much larger than $50 \mu \mathrm{m}$ and could be as large as $300 \mu \mathrm{m}$ (Fig. 4d). Further magnification of the surface of the granules produced (Fig. 4e and f) show that they are apparently held together by the liquid. Thus, the adsorbed oily liquid is apparently acting as the granulating agent for
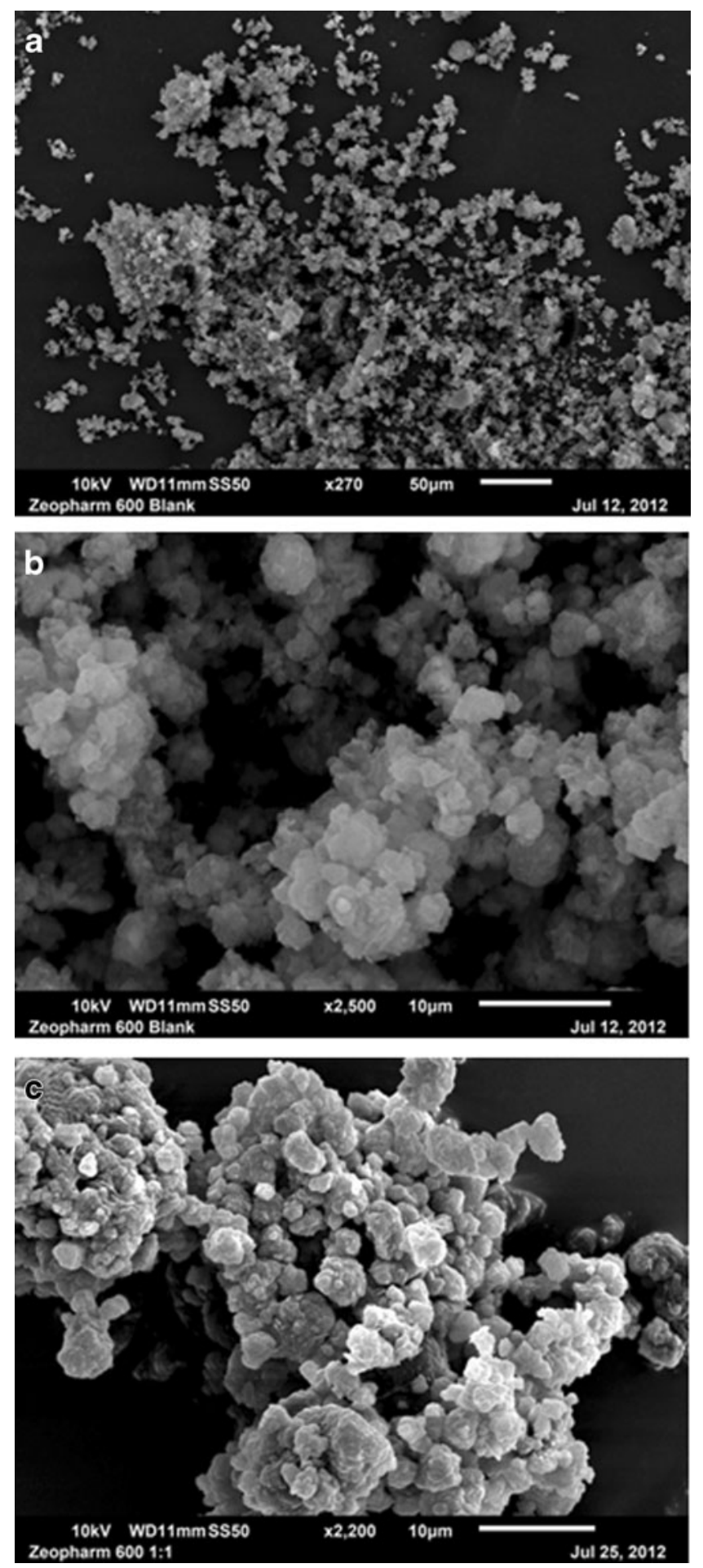

Fig. 6 SEM images of neat Zeopharm ${ }^{\circledR} 600$ at $270 \times(\mathbf{a})$ and $2500 \times(\mathbf{b})$ magnifications and after adsorption with 1:1 w/W PEG-35 castor oil (Cremophor ${ }^{\circledR}$ EL) at $2200 \times$ (c) magnification. A microscope scale is shown with each image for comparison.

the Aerosil ${ }^{\circledR} 200$ and is interspersed in between particles. This might be the mechanism how the silicates work as adsorption media for such liquids. Since particle size of Aerosil ${ }^{\circledR} 200$ is extremely low, any possibility of the existence 


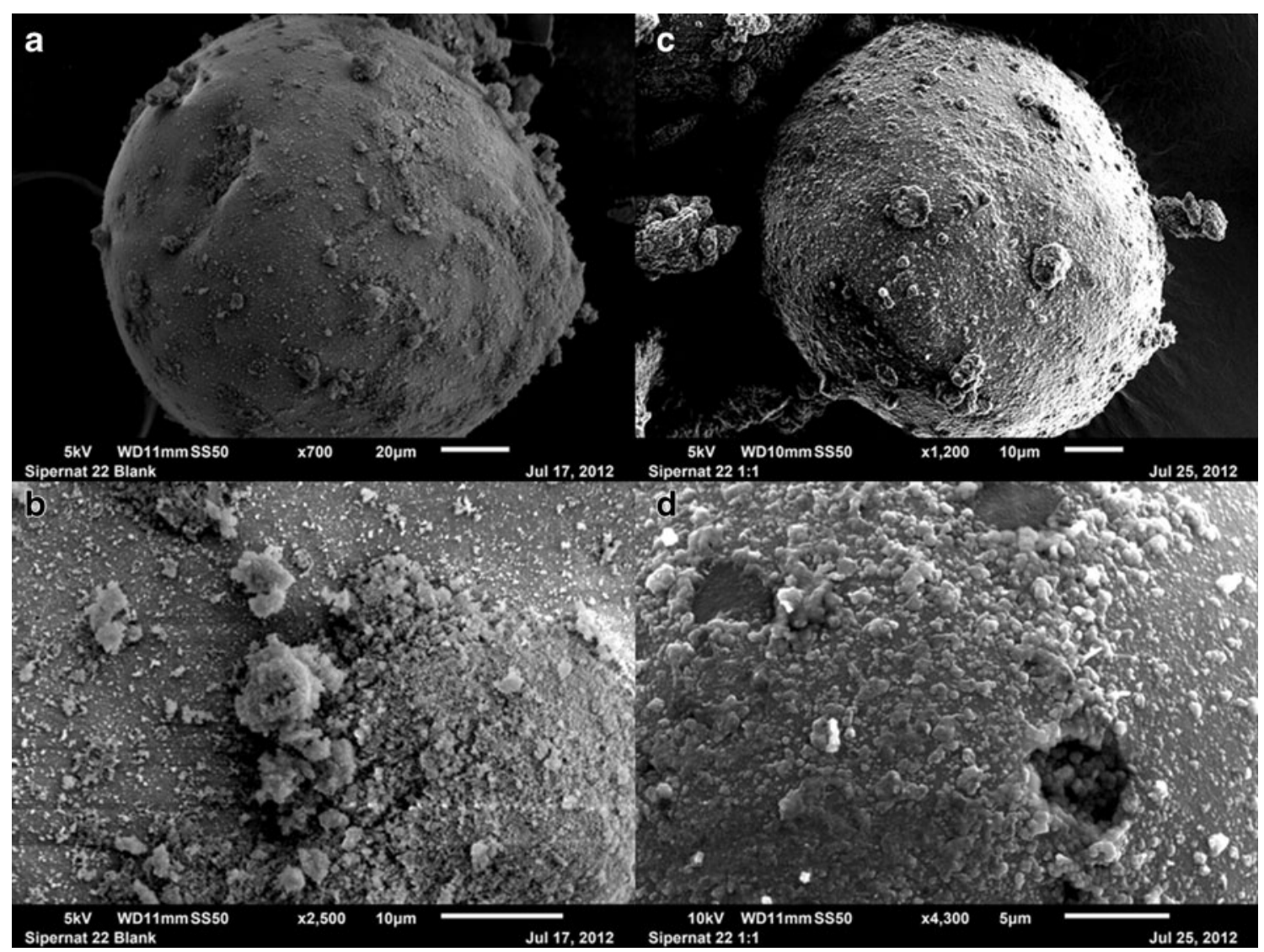

Fig. 7 SEM images of neat Sipernat ${ }^{\circledR} 22$ at $700 \times(\mathbf{a})$ and $2500 \times(\mathbf{b})$ magnifications and after adsorption of I : I w/w PEG-35 castor oil (Cremophor $®$ EL) at $1200 \times(\mathbf{c})$ and $4300 \times$ (d) magnifications. Scales of individual images are shown for comparison.

of sizable pores and the adsorption of lipids and surfactants into such pores appear to be low. Aerosil ${ }^{\circledR} 200$ is not inherently tabletable. The presence of liquids at the surface of the silicate rather than inside pores and the possibility of their squeezing out under pressure from granules formed might even add to its lack of tabletability.

\section{Sylysia ${ }^{\circledR} 350$}

This silicate shows SEM micrographs very similar to those of Aerosil ${ }^{\circledR}$ 200. The left hand column of Fig. 5 shows SEM images of Sylysia ${ }^{\circledR} 350$ at 1500×, 3700× and 5500× (Fig. 5a, $\mathrm{b}$ and c, respectively) with the embedded measuring scales of 10,5 and $2 \mu \mathrm{m}$, respectively. It is apparent from these images that the material exists as loose aggregates of very fine particles. Even at the scale of $2 \mu \mathrm{m}$ (Fig. $5 \mathrm{c}$ ), the aggregates can be distinctly observed, and the size of the individual particles appear to be much less than $1 \mu \mathrm{m}$. Thus, the reported particle size of $1.8 \mu \mathrm{m}$, as noted in Table I, seems to be higher than what we observed in the SEM images.

Again, very similar to Aerosil ${ }^{\circledR} 200$, Sylysia ${ }^{\circledR} 350$ forms granules in presence of Cremophor ${ }^{\circledR}$ EL at the 1:1 w/w ratio (Fig. 5d, e and $\mathrm{f}$ at, respectively, $700 \times, 3000 \times$ and $6000 \times$ magnifications) and the liquid is distributed inside as well as at the surface of the granules formed. Sylysia ${ }^{\circledR} 350$ is inherently poorly tabletable, and the adsorption of oily liquids onto the relatively large surface area of very small particles would make the material even less tabletable.

\section{Zeopharm ${ }^{\circledR} 600$}

Figure $6 \mathrm{a}$ and $\mathrm{b}$ give the SEM micrographs of neat Zeopharm ${ }^{\circledR} 600$ at $270 \times$ and $2500 \times$ magnifications. The reported particle size of Zeopharm ${ }^{\circledR}$ is $6 \mu \mathrm{m}$ (Table I). However, at the scale of $10 \mu \mathrm{m}$ in Fig. 6b, the material appears to be agglomerates of very fine particles and even the size of the agglomerates appears to be much less than $6 \mu \mathrm{m}$. It appears that the size of individual particles would be less than $1 \mu \mathrm{m}$ and thus the particle size of Zeopharm ${ }^{\circledR}$ appears to be closer to those of Aerosil ${ }^{\circledR} 200$ and Sylysia ${ }^{\circledR}$ 350. It is evident that like Aerosil ${ }^{\circledR} 200$ and Sylysia ${ }^{\circledR} 350$, Cremophor ${ }^{\circledR}$ EL is distributed on the surface of Zeopharm ${ }^{\circledR} 600$ after adsorption (Fig. 6c), which is responsible for the poor tabletability observed.

\section{Sipernat ${ }^{\circledR} 22$}

It is a precipitated silica with the reported particle size of $120 \mu \mathrm{m}$ (Table I). The left hand column of Fig. 7 shows the 

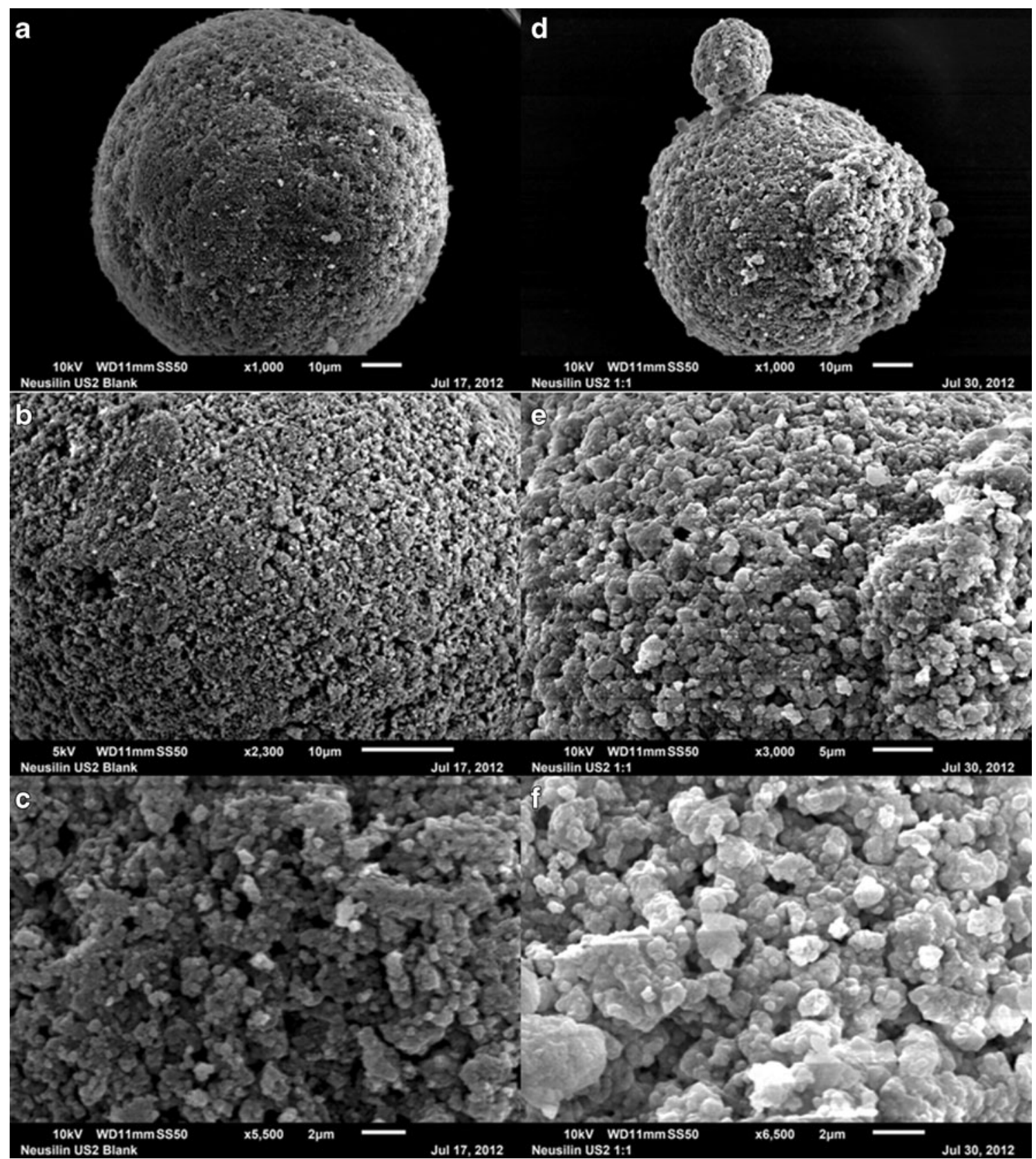

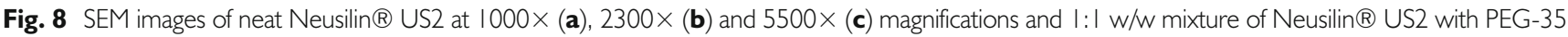
castor oil (Cremophor ${ }^{\circledR}$ EL) at $1000 \times(\mathbf{d}), 3000 \times(\mathbf{e})$ and $6500 \times(\mathbf{f})$ magnifications. Microscope scales are shown with the images for comparison of dimensions.

surface of Sipernat ${ }^{\circledR} 22$ at $700 \times$ and $2500 \times$ (Fig. 7a and b, respectively), while the right hand column of the figure depicts the surface of the material at $1200 \times$ and $4300 \times($ Fig. $7 \mathrm{c}$ and $d$, respectively) after the adsorption of Cremophor ${ }^{\circledR}$ EL at 1:1 $\mathrm{w} / \mathrm{w}$ ratio. The particles appeared to be rigid with a relatively smooth surface and, unlike Neusilin ${ }^{\circledR}$ US2 discussed below, no relatively large pores were visible. When Cremophor ${ }^{\circledR}$ EL was adsorbed onto Sipernat ${ }^{\circledR} 22$, it was inferred from the SEM pictures that the liquid might have formed a layer at the surface. The rigidity of the particles and the spreading of oily liquids at the surface of individual particles could be the possible reasons for poor tabletability of Sipernat ${ }^{\circledR} 22$ before and after adsorption of Cremophor ${ }^{\circledR}$ EL.

\section{Neusilin $\AA^{\circledR}$ US2}

The SEM micrographs of neat Neusilin ${ }^{\circledR}$ US2 at $1000 \times$, $2300 \times$ and $5500 \times$ magnifications are shown in the left column of Fig. 8a, b and c, respectively. It is clearly evident from these figures that Neusilin ${ }^{\circledR}$ US2 is a granular and 
highly porous material with relatively large pores. Figure 8c indicates that the pore size could be as large as $1 \mu \mathrm{m}$ in diameter. However, Neusilin ${ }^{\circledR}$ US2 has been reported in the literature to be mesoporous (7). According to the IUPAC (International Union of Pure and Applied Chemistry) guidelines, mesoporous materials have pores in the range of $2-$ $50 \mathrm{~nm}$, while the pore size is $<2 \mathrm{~nm}$ for microporous materials and $>50 \mathrm{~nm}$ for macroporous materials (7). Because of the small size, any micro- and meso-pores present in Neusilin ${ }^{\circledR}$ US2 would not be visible under SEM, and, therefore, the large pores observed in Fig. 8a, b and $\mathrm{c}$ indicate that Neusilin ${ }^{\circledR}$ US2 is also highly macroporous.

The macropores were still visible when Cremophor ${ }^{\circledR}$ EL was adsorbed onto Neusilin ${ }^{\circledR}$ US2 (Fig. 8d, e and f). Thus, it appears that most of the oily liquid was adsorbed into mesopores and deep into the channels of macropores of the silicate. A comparison of the SEM micrographs on the right hand side versus the left hand side column of Fig. 8 indicates that the liquid might have also partially spread on the surface of particles. There was only the partial spreading of liquid at
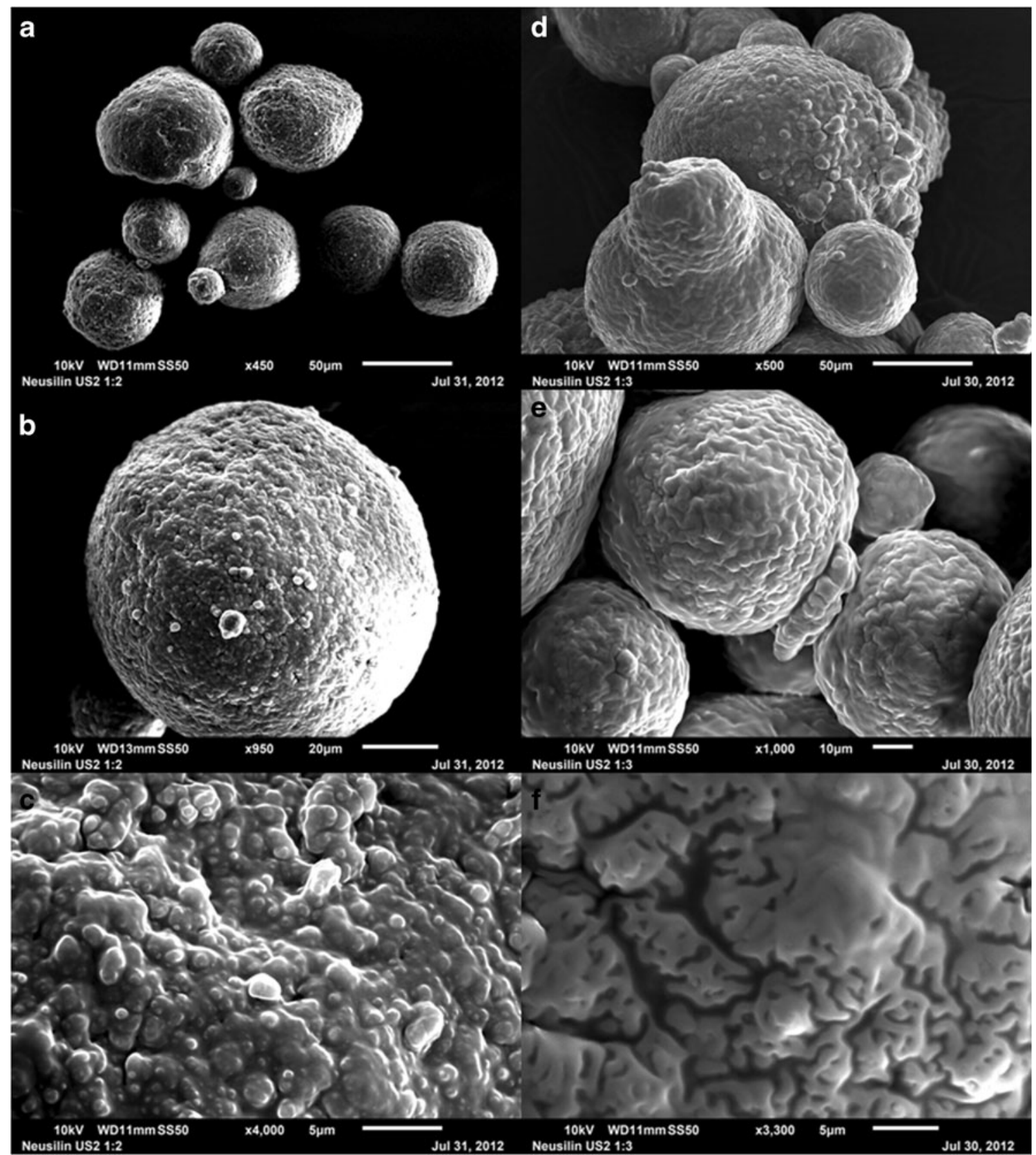

Fig. 9 SEM images of Neusilin ${ }^{\circledR}$ US2 loaded with I:2 w/w PEG-35 castor oil (Cremophor $®$ EL) at $450 \times(\mathbf{a}), 950 \times(\mathbf{b})$ and $4000 \times(\mathbf{c})$ magnifications and loaded with 1:3 w/w Cremophor ${ }^{\circledR}$ EL at $500 \times(\mathbf{d}), 1000 \times(\mathbf{e})$ and $3300 \times(\mathbf{f})$ magnifications. Microscopic scales are shown with the images for comparison. 

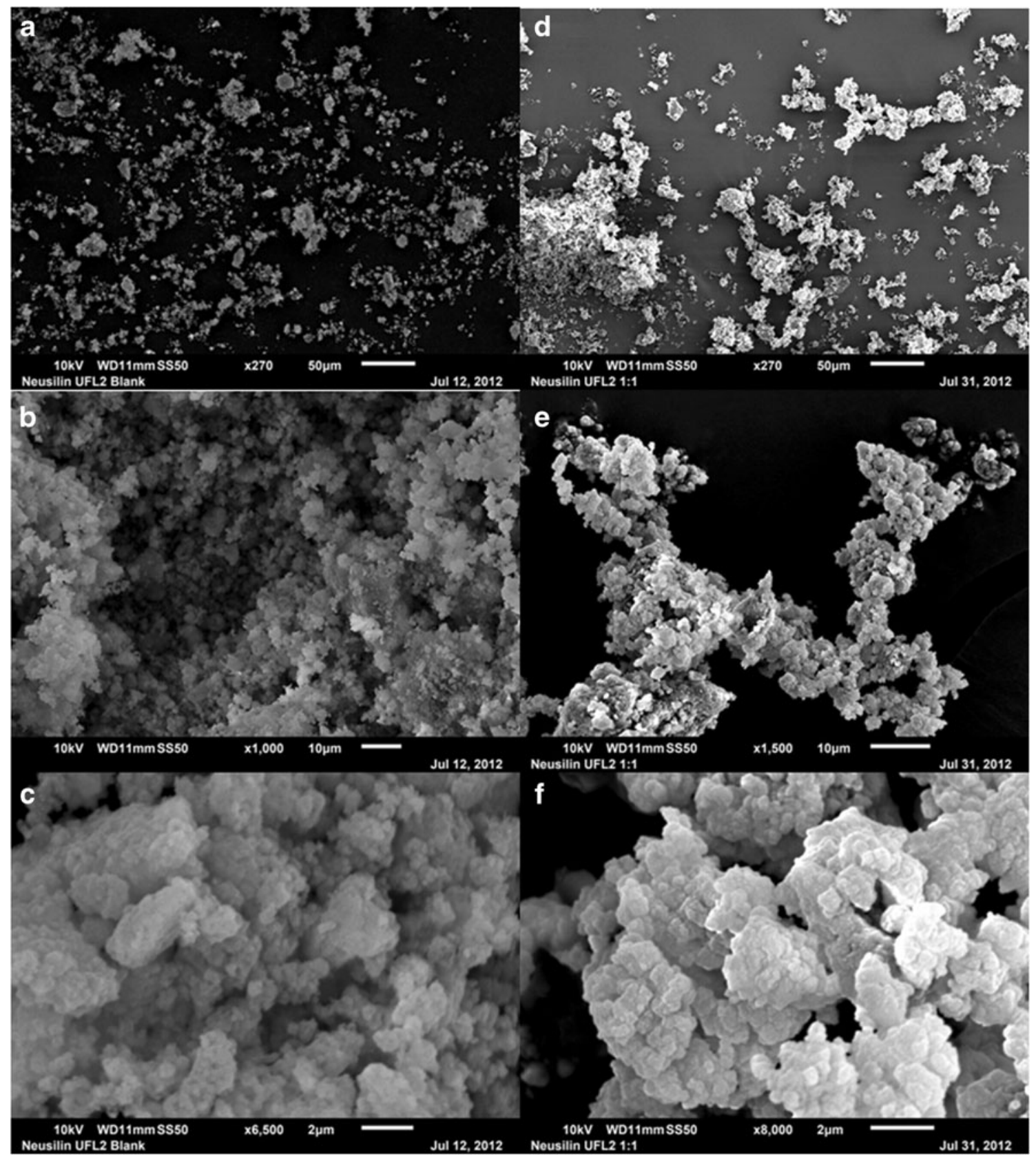

Fig. 10 SEM images of neat Neusilin $®$ UFL2 at $270 \times(\mathbf{a}), 1000 \times(\mathbf{b})$ and $6500 \times(\mathbf{c})$ magnifications and I: I w/w mixture of Neusilin ${ }^{2}$ UFL2 with PEG-35 castor oil (Cremophor ${ }^{\circledR}$ EL) at $270 \times(\mathbf{d}), 1500 \times(\mathbf{e})$ and $8000 \times(\mathbf{f})$ magnifications. Microscope scales are shown with the images for comparison of dimensions.

the surface of Neusilin ${ }^{\circledR}$ US2, the remaining being adsorbed within meso- and macro-pores below the surface. This may possibly explain why Neusilin ${ }^{\circledR}$ US2 lost tabletability only partially and still maintained acceptable tableting properties in comparison with other silicates where most of the liquid adsorbed on the surface.

As noted in Table I, Neusilin ${ }^{\circledR}$ US2 is a granular substance, and it is possible that its porosity is due to relatively large channels formed within the granules. Figure 9 shows the effect of increasing Cremophor ${ }^{\circledR}$ EL content of the mixture on the surface of the silicate. When two parts of Cremophor ${ }^{\circledR}$ EL was mixed with 1 part of Neusilin ${ }^{\circledR}$ US2 $(\mathrm{w} / \mathrm{w})$, the liquid covered most of the pores and appeared to have also been deposited on the surface of the silicate (Fig. 9a, b and c at, respectively, 450×, 950× and 4000× magnifications). Further covering of the surface by Cremophor ${ }^{\circledR}$ EL is evident when its concentration was increased to 1:3 w/w (Fig. 9d, e and f at, respectively, $500 \times, 1000 \times$ and $3300 \times$ magnifications). Although materials at 1:2 and 1:3 silicate to surfactant ratios were still 
powders, they were, however, not tabletable due the presence of oily liquid at the surface that hindered interparticulate bonding.

\section{Neusilin ${ }^{\circledR}$ UFL2}

Neusilin ${ }^{\circledR}$ UFL2 has similar chemical composition to that of Neusilin ${ }^{\circledR}$ US2; however, it reportedly has low particle size (Table I). The left hand column of Fig. 10 shows the SEM images of neat Neusilin ${ }^{\circledR}$ UFL2 at $270 \times, 1000 \times$ and $6500 \times$ magnifications (Fig. 10a, b and c, respectively). The material is composed of the agglomerates of very fine particles. Even at the scale of $2 \mu \mathrm{m}$, it appears to be agglomerates (Fig. 10c) and, thus, it appears that the size of individual particles in Neusilin ${ }^{\circledR}$ UFL2 is in the submicron range $(<1 \mu \mathrm{m})$. With

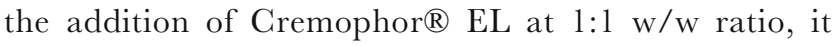
appeared that the liquid was adsorbed within the mesopores and macropores of the silicate, and, therefore, the material appeared to remain as fine particles (Fig. 10d, e and f). A close comparison between Fig. 10b and e indicates that there was also some agglomeration of powders, possibly because of the surface adsorption of liquid. Upon further increase of Neusilin ${ }^{\circledR}$ UFL2 to Gremophor ${ }^{\circledR}$ EL ratios to $1: 2$ and 1:3 $\mathrm{w} / \mathrm{w}$, the granulation progressed with the inter-particulate distribution of the liquid. Due to such an adsorption of oily liquids at the surface of and in between particles (Fig. 11), Neusilin ${ }^{\circledR}$ UFL2 does not demonstrate acceptable tabletability in presence of liquids (Fig. 1).

\section{CONCLUSIONS}

Although silicates are commonly used in the pharmaceutical dosage form development as glidants, there has been a recent interest in its application as adsorbents for the development of solid dosage forms of liquid lipid-based drug delivery systems. However, no systematic study has been conducted on whether various silicates available for pharmaceutical application are tabletable or not, whether the liquids are adsorbed on the surface or inside the pores of silicates, and what influence the adsoption of liquids have on their tabletability. Among the six silicates studied in the present investigation, three (Aerosil® 200, Sipernat ${ }^{\circledR} 22$ and Sylysia $\left.{ }^{\circledR} 350\right)$ were primarily composed of silicon dioxide and, when compressed in presence of $20 \% \mathrm{w} / \mathrm{w}$ microcrystalline cellulose, all of them were found to be non-tabletable as the tablets did not achieve a minimum tensile strength of $1 \mathrm{MPa}$ at the wide range of compression pressure used. The
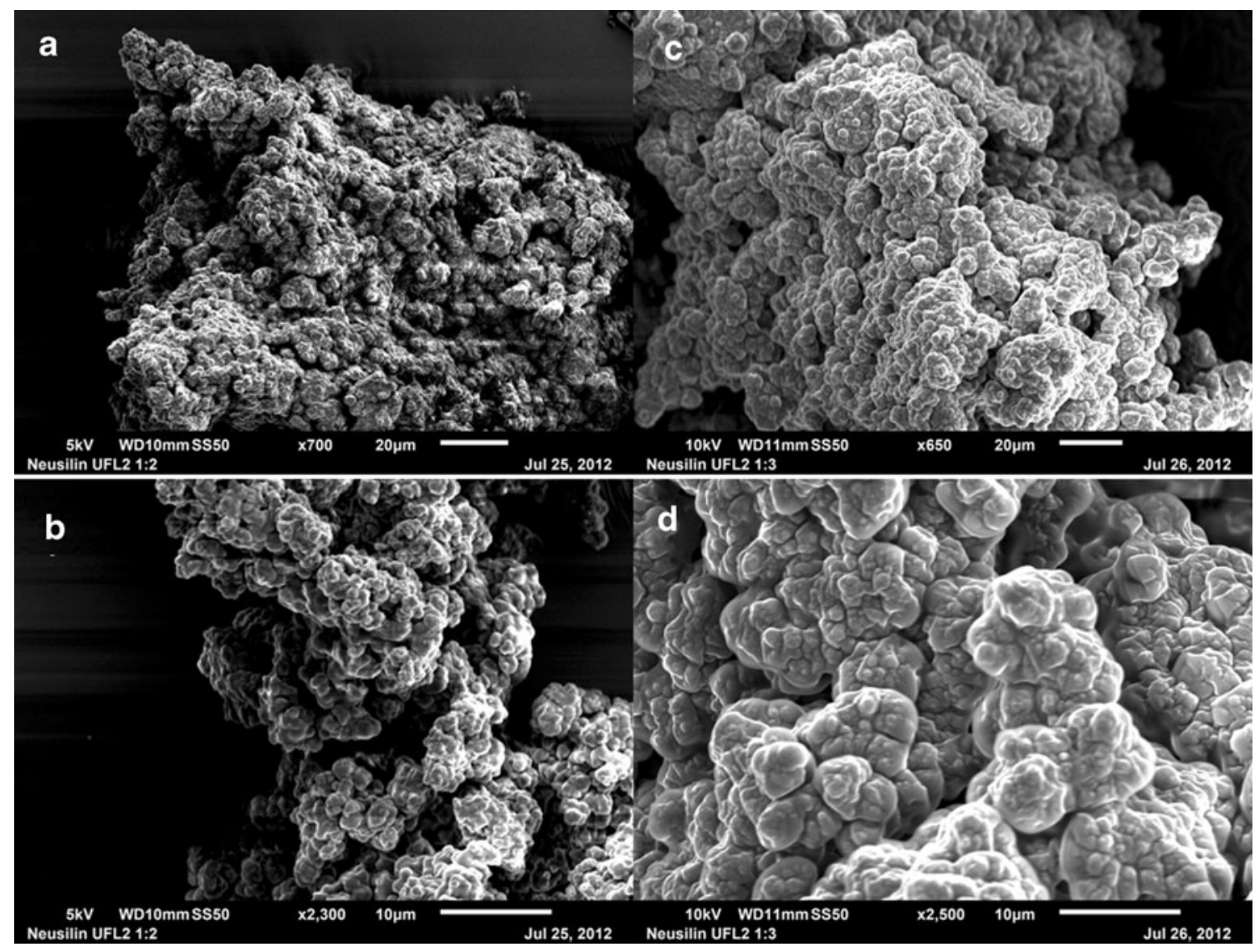

Fig. I I SEM images of Neusilin $\AA$ UFL2 loaded with 1:2 w/w PEG-35 castor oil (Cremophor $\AA$ EL) at $700 \times(\mathbf{a})$ and $2300 \times(\mathbf{b})$ magnifications and loaded with 1:3 w/w Cremophor ${ }^{\circledR}$ EL at $650 \times(\mathbf{c})$ and $2500 \times(\mathbf{d})$ magnifications. Microscopic scales are shown with the images for comparison. 
adsorption of three different liquid components of lipid based drug delivery systems, namely, Capmul ${ }^{\circledR}$ MCM (glycerol monocaprylocaprate), Captex ${ }^{\circledR} 355$ (caprylic/capric triglycerides) and Cremophor ${ }^{\circledR}$ EL (PEG-35 castor oil), at $1: 1 \mathrm{w} / \mathrm{w}$ ratios showed that the mixtures still remained powders and their tabletability further decreased. The SEM images of mixtures with one of these liquids (Cremophor ${ }^{\circledR}$ EL) indicated that the adsorbed liquid remained primarily at the surface of particles rather than inside any pores and, as a result, the particles did not compact into tablets. Zeopharm ${ }^{\circledR} 600$, another silicate used in the present investigation, is reported to contain calcium oxide $(24 \% \mathrm{w} / \mathrm{w})$ along with silicon dioxide $(57 \% \mathrm{w} / \mathrm{w})$ and it demonstrated good tabletability in absence of any adsorbed liquid. However, when Cremophor EL was adsorbed onto it at 1:1 w/w ratio, it lost its tabletability since the SEM micrographs demonstrated that the liquid was adsorbed onto the surface of solid particles creating interparticulate barriers in physical bonding during compression. Neusilin ${ }^{\circledR}$ US2 and Neusilin ${ }^{\circledR}$ UFL2, which are the remaining two silicates used in the present investigation, are chemically similar containing mixtures of aluminum oxide $(32 \%)$, magnesium oxide $(12 \%)$ and silicon dioxide $(32 \%)$. Both of them showed acceptable tabletability when compressed without the addition of a liquid lipid or surfactant. However, when Cremophor ${ }^{\circledR}$ EL was adsorbed onto these materials at 1:1 w/w, only Neusilin ${ }^{\circledR}$ US2 could retain acceptable tabletability while Neusilin ${ }^{\circledR}$ UFL2 demonstrated minimally acceptable tabletability only at a low compression pressure of $45 \mathrm{MPa}$ and it failed to demonstrate acceptable tabletability when the compression pressure was increased. These results could be explained by the SEM photomicrographs, which showed that the liquid was adsorbed into the pores of relatively large particles of Neusilin ${ }^{\circledR}$ US2, while in case of Neusilin ${ }^{\circledR}$ UFL2 the liquid was distributed at the surface.

From the above summary, a trend appears in the mechanism of tabletability of different silicates. The silicates used in the present study can be divided into two chemical groups: one containing 98-100\% silicon dioxide (Aerosil ${ }^{\circledR} 200$, Sipernat ${ }^{\circledR} 22$ and Sylysia ${ }^{\circledR} 350$ ), and the other containing much lesser amount of silicon dioxide $(32-57 \%)$, the rest being aluminum oxide, magnesium oxide or calcium oxide (Neusilin US2, Neusilin UFL2 and Zeopharm 600). In the absence of adsorbed liquids, the second group was tabletable, while the first was not. Thus, the chemical composition plays a major role in the tabletability of silicates. Since there were big differences in particle sizes of Neusilin ${ }^{\circledR}$ US2, Neusilin ${ }^{\circledR}$ UFL2 and Zeopharm ${ }^{\circledR} 600$, it appeared that the particle size did not have major influence on the tabletability of silicates in the absence of adsorbed liquids . However, whether these silicates would retain their tabletability after adsorption of liquids appears to be dependent on particle size and possibly porosity. This is evident from the greater loss of tabletability of Neusilin ${ }^{\circledR}$ UFL2 and Zeopharm ${ }^{\circledR} 600$ (silicates with lower particle size) than that of Neusilin ${ }^{\circledR}$ US2 (silicate with larger particle size). The porosity might be important as the porous channels could be deeper in larger particles to retain the adsorbed lipids during compression. Further studies are, however, needed to elucidate mechanisms of why and how the chemical composition influences the tabletability of silicates and the effect of particle size and porosity on the tabletability after the adsorption of lipidic materials.

It may be concluded that, among all the silicates used in the present investigation, only Neusilin ${ }^{\circledR}$ US2 has both the surface morphology and the porosity for use as the carrier in the development of tablet formulations of lipid-based drug delivery systems. The amount of liquid lipidic materials used should, however, be limited. When the ratio of Neusilin ${ }^{\circledR}$ US to the liquid was $1: 1 \mathrm{w} / \mathrm{w}$, there was acceptable tabletability, and it decreased below the acceptable limit when the liquid component was increased to $1: 2$ and 1:3 $\mathrm{w} / \mathrm{w}$ ratios. It is hoped that the systematic approach adopted in the present investigation will help the selection of silicates from those currently available commercially. It may also provide guidance for the synthesis of newer silicates for the development of tablets containing lipid components.

\section{ACKNOWLEDGMENTS AND DISCLOSURES}

The present study was supported, in part, by a research grant from ABITEC Corporation, 501 W. 1st Avenue, Columbus, OH 43215, USA.

Open Access This article is distributed under the terms of the Creative Commons Attribution License which permits any use, distribution, and reproduction in any medium, provided the original author(s) and the source are credited.

\section{REFERENCES}

1. Gupta MK, Tseng YC, Goldman D, Bogner RH. Hydrogen bonding with adsorbent during storage governs drug dissolution from solid-dispersion granules. Pharm Res. 2002;19(11):1663-72.

2. Mellaerts R, Jammaer JAG, Van Speybroeck M, Chen H, Humbeeck JV, Augustijns P, et al. Physical state of poorly water soluble therapeutic molecules loaded into SBA-15 ordered mesoporous silica carriers: a case study with itraconazole and ibuprofen. Langmuir. 2008;24(16):8651-9.

3. Sander C, Holm P. Porous magnesium aluminometasilicate tablets as carrier of a cyclosporine self-emulsifying formulation. AAPS PharmSciTech. 2009;10(4):1388-95.

4. Van Speybroeck M, Barillaro V, Thi TD, Mellaerts R, Martens J, Van Humbeeck J, et al. Ordered mesoporous silica material SBA15: a broad-spectrum formulation platform for poorly soluble drugs. J Pharm Sci. 2009;98(8):2648-58. 
5. Van Speybroeck M, Mellaerts R, Mols R, Thi TD, Martens JA, Van Humbeeck J, et al. Enhanced absorption of the poorly soluble drug fenofibrate by tuning its release rate from ordered mesoporous silica. Eur J Pharm Sci. 2010;41(5):623-30.

6. Limnell T, Santos HA, Mäkilä E, Heikkilä T, Salonen J, Murzin DY, et al. Drug delivery formulations of ordered and nonordered mesoporous silica: comparison of three drug loading methods. J Pharm Sci. 2011;100(8):3294-306.

7. Qian KK, Bogner RH. Application of mesoporous silicon dioxide and silicate in oral amorphous drug delivery systems. J Pharm Sci. 2012;101(2):444-63.

8. Milovic M, Djuris J, Djekic L, Vasiljevic D, Ibric S. Characterization and evaluation of solid self-microemulsifying drug delivery systems with porous carriers as systems for improved carbamazepine release. Int J Pharm. 2012;436:58-65.

9. Liao G-C, Jarowski CI. Dissolution rates of corticoid solutions dispersed on silicas. J Pharm Sci. 1984;73(3):401-3.

10. Patil P, Joshi P, Paradkar A. Effect of formulation variables on preparation and evaluation of gelled self-emulsifying drug delivery system (SEDDS) of ketoprofen. AAPS PharmSciTech. 2004;5(3):43-50.

11. Ito Y, Arai H, Uchino K, Iwasaki K, Shibata N, Takada K. Effect of adsorbents on the absorption of lansoprazole with surfactant. Int J Pharm. 2005;289(1-2):69-77.

12. Ito Y, Kusawake T, Ishida M, Tawa R, Shibata N, Takada K. Oral solid gentamicin preparation using emulsifier and adsorbent. J Control Release. 2005;105(1-2):23-31.

13. Agarwal V, Siddiqui A, Ali H, Nazzal S. Dissolution and powder flow characterization of solid self-emulsified drug delivery system (SEDDS). Int J Pharm. 2009;366(1-2):44-52.

14. Dixit RP, Nagarsenker MS. Optimized microemulsions and solid microemulsion systems of simvastatin: characterization and in vivo evaluation. J Pharm Sci. 2010;99(12):4892-902.

15. Khan MA, Nazzal S, Zaghloul A-A. Effect of extragranular microcrystalline cellulose on compaction, surface roughness, and in vitro dissolution of a self-nanoemulsified solid dosage form of ubiquinone. Pharm Technol North Am. 2002;26(4):86-98.
16. Hentzschel GM, Alnaief M, Simirnova I, Sakmann A, Leopold CS. Tableting properties of silica aerogel and other silicates. Drug Dev Ind Pharm. 2012;38(4):462-7.

17. Mura P, Valleri M, Cirri M, Mennini N. New solid self-emulsifying systems to enhance dissolution of poorly water soluble drugs. Pharm Dev Tech. 2012;17(3):277-84.

18. Prajapati HN, Dalrymple DM, Serajuddin ATM. A comparative evaluation of mono-, di- and triglyceride of medium chain fatty acids by lipid/surfactant/water phase diagram, solubility determination and dispersion testing for application in pharmaceutical dosage form development. Pharm Res. 2011;29(1):285-305.

19. Tomas I, Kleinschmidt S. Improvement of flowability of fine cohesive powders by flow additives. Chem Eng Technol. 2009;32:1470 83.

20. Shi L, Sun CC. Transforming powder mechanical properties by core/shell structure: compressible sand. J Pharm Sci. 2010;99(11):4458-62.

21. Fell J, Newton J. Determination of tablet strength by the diametral compression test. J Pharm Sci. 1970;59(5):688-91.

22. Patil P, Paradkar A. Porous polystyrene beads as carriers for selfemulsifying system containing loratadine. AAPS PharmSciTech. 2006;7(1):199-205.

23. Hentzschel CM, Sakmann A, Leopold CS. Suitability of various excipients as carrier and coating materials for liquisolid compacts. Drug Dev Ind Pharm. 2011;37:1200-7.

24. Sun CG. Decoding powder tabletability: roles of particle adhesion and plasticity. J Adhes Sci Technol. 2011;4(5):483-99.

25. Amidon GE, Secreast PJ, Mudie D. Chapter 8 - Particle, powder, and compact characterization. In: Developing solid oral dosage forms. San Diego: Academic; 2009. p. 163-86.

26. Nazzal S, Nutan M, Palamakula A, Shah R, Zaghloul AA, Khan MA. Optimization of a self-nanoemulsified tablet dosage form of ubiquinone using response surface methodology: effect of formulation ingredients. Int $\mathrm{J}$ Pharm. $2002 ; 240(1-2): 103-14$. 